\title{
Pursuing climate resilient coffee in Ethiopia - a critical review
}

Article

Accepted Version

Creative Commons: Attribution-Noncommercial-No Derivative Works 4.0

Hirons, M., Mehrabi, Z., Gonfa, T. A., Morel, A., Gole, T. W., McDermott, C., Boyd, E., Robinson, E., Sheleme, D., Malhi, Y., Mason, J. and Norris, K. (2018) Pursuing climate resilient coffee in Ethiopia - a critical review. Geoforum, 91. pp. 108116. ISSN 0016-7185 doi:

https://doi.org/10.1016/j.geoforum.2018.02.032 Available at https://centaur.reading.ac.uk/75917/

It is advisable to refer to the publisher's version if you intend to cite from the work. See Guidance on citing.

Published version at: http://dx.doi.org/10.1016/j.geoforum.2018.02.032

To link to this article DOI: http://dx.doi.org/10.1016/j.geoforum.2018.02.032

Publisher: Elsevier

All outputs in CentAUR are protected by Intellectual Property Rights law, including copyright law. Copyright and IPR is retained by the creators or other copyright holders. Terms and conditions for use of this material are defined in the End User Agreement.

\section{www.reading.ac.uk/centaur}

\section{CentAUR}


Central Archive at the University of Reading

Reading's research outputs online 


\title{
Pursuing climate resilient coffee in Ethiopia - A critical review
}

Hirons $^{1}$, M., Mehrabi ${ }^{2}$, Z., Gonfa ${ }^{3}$, T.A. Morel ${ }^{1,4}$, A., Gole ${ }^{3}$, T.W., McDermott ${ }^{1}$, C., Boyd ${ }^{5}$, E., Robinson ${ }^{6}$, E., Sheleme ${ }^{3}$, D., Malhi ${ }^{1}$, Y., Mason ${ }^{7}$, J., Norris ${ }^{3}, \mathrm{~K}$.

1. Environmental Change Institute (ECI), School of Geography and the Environment, University of Oxford, UK

2. Institute for Resources, Environment and Sustainability, University of British Columbia, Canada

3. Environment, Climate Change and Coffee Forest Forum, Addis Ababa, Ethiopia

4. Institute of Zoology, Zoological Society of London, UK

5. LUCSUS (Lund University Centre for Sustainability Studies), Lund University, Sweden

6. School of Agriculture, Policy and Development, University of Reading, UK

7. Nature Conservation Research Centre, Ghana

\begin{abstract}
This paper provides a multi-scalar examination of the Ethiopian coffee sector and its pursuit of climate resilience. Concern is growing about the potential impact of climate change on Arabica coffee in Ethiopia and the 25 million livelihoods it supports. Arabica coffee has a relatively narrow envelope of climatic suitability and recent studies suggest that the area of bioclimatically suitable space for the species in its native Ethiopia could decline dramatically in the coming decades. We adopt a critical perspective on resilience that reflects on the situated nature of the ecology/science of coffee and climate change and the operation of social, economic, and discursive power across scales, paying particular attention to the differentiated impacts of climate change and associated resilience strategies. This analysis begins by reviewing Ethiopia's Climate Resilient Green Economy strategy and argues that the current lack of attention to coffee is inappropriate considering the coffee sector's vulnerability to climate change, economic importance and association with forests. The paper then examines the contemporary coffee sector which provides the context for reflecting on three potential responses to the threat climate change poses; a spatial response from farmers, adaptive farm management responses such as changing shade levels and the development of the country's genetic resources to cultivate improved varieties. The analysis explores the disconnect between the interventions emerging from national and international institutions and the local context. The multi-scale approach highlights the presence of complex normative trade-offs associated with pursing climate resilience strategies and reinforces the importance of appreciating the dynamics which influence decision-making in the country.
\end{abstract}

Keywords: Arabica coffee, Forest Governance, Climate Change, Resilience, Ethiopia,

\section{Introduction}

Since Arabica coffee (Coffea arabica L.) spread from Ethiopia to the Yemen peninsula, potentially as early as 575 AD (Anthony et al., 2002), coffee has become a globally significant agricultural commodity with more than a billion cups consumed every day. In 2014, more than 8.5 million tonnes were produced by 26 million farmers in 52 countries with an export value of 39.3 billion US\$ (ICO, 2016; UNCOMTRAD, 2014). Despite robust demand, concern is growing within the sector about the impact of climate change which could reduce the suitable area for growing Arabica coffee by up to $50 \%$ globally by 2050 (Bunn et al., 2015).

Although Ethiopia only accounts for 4-5\% of global coffee production (ICO, 2016), it commands a central position in the sector because it contains most of the global genetic diversity of Arabica coffee (Labouisse et al., 2008). This genetic resource is critical to developing varieties which are more resistant to the impacts of climate change, pests and diseases without compromising taste and quality (Hein and Gatzweiler, 2006; Mehrabi and Lashermes, 2017; van der Vossen et al., 2015). In 
addition to the global importance of Ethiopia's genetic resources, coffee plays a central role in the national economy and the livelihoods of approximately 4.5 million farmers (EEA, 2015). In 2014 the country produced 398,000 tonnes (ICO, 2016) with an export value of approximately 1 billion US\$ (UNCOMTRAD, 2014), with coffee accounting for 25-30\% of total export revenues (Tefera, 2012). As elsewhere, coffee in Ethiopia is vulnerable to climate change. Modelling studies by Moat et al. (2017) suggests that the area of bioclimatically suitable space of Arabica coffee could decline between $~ 39-59 \%$ by the end of the century, depending on the emissions scenario.

Growing recognition of the vulnerability of coffee to climate change has amplified interest in developing resilience in the sector in Ethiopia (Kew, 2013). Addressing resilience, defined by (Adger, 2000:347) as 'the ability of groups or communities to cope with external stresses and disturbances as a result of social... and environmental change' is viewed as an imperative in Ethiopia's coffee sector, enabling it to continue to contribute to the long-term economic and social well-being of the country, its citizens, coffee companies and millions of consumers. Despite the growing intensity of these calls, attention in the academic literature has focussed predominantly on the agro-ecology of the coffee crop (Davis et al., 2012; Jaramillo et al., 2009; Jaramillo et al., 2011; Perfecto and Vandermeer, 2015) or structural issues in the international coffee market, particularly the asymmetries of power in the value chain, (Arslan and Reicher, 2011; Daviron and Ponte, 2005; Petit, 2007; Ponte, 2002a) and generally neglected more nuanced, localised and field-based assessments of the social and economic dynamics which will underpin the capacity of sector to cope with and adapt to climate change.

Over the preceding decades, resilience has emerged as a major strand of interdisciplinary research and policy-practice at the intersection of society and nature (Folke, 2006). Although the term refers to a variety of theoretical and conceptual approaches to social-ecological problems, in general the field has been characterised by a normative, coherently systematic and reformist approach (Kull and Rangan, 2016). More critical approaches to researching socio-ecological problems (Robbins, 2012) tend to be less reformist and challenge institutional and social status quos. Here we adopt a critical realist stance (Forsyth, 2001) that does not deny the material realities of climate change or its impact on coffee and the consequential need to develop appropriate policy responses. But instead of adopting the normative framing of 'mainstream' resilience theory (Folke et al., 2005; Olsson et al., 2006; RA, 2010; Walker et al., 2004) this analysis focuses on the situated nature of the ecology/science of coffee and climate change, the operation of social, economic, and discursive power across scales and it pays particular attention to who wins, who loses, and the differentiated impacts of climate change and associated strategies developed or proposed in pursuit of resilience (Forsyth, 2008; Kull et al., 2015; Marino and Ribot, 2012).

This approach facilitates an interrogation of key concerns regarding the divergence of socioeconomic and ecological research and the multi-scalar contestations concerning the subjects of interdisciplinary socio-ecological research (Christopher Brown and Purcell, 2005; Görg, 2007; Green, 2016; Mauro, 2009), in particular, in the pursuit of climate resilient coffee in Ethiopia. This study also extends the analysis beyond markets and states (Ostrom, 2010) and unravels the complexity of actual governance regimes which operate in diffuse, emergent, self-organising modes across a range of scales. In doing so we hope to enrich understandings of the complex issues facing policy-makers and donors seeking to pursue climate resilience. In particular, the study reviews the context in which discussions concerning climate resilience in Ethiopia's coffee sector are occurring. This has been noted as an essential pre-requisite for understanding the processes related to the development of climate resilience and adaptation strategies (Moser and Ekstrom, 2008).

The aim of this paper is to critically reflect on how emerging climate resilience strategies in Ethiopia's coffee sector entail poorly articulated trade-offs between competing priorities among 
different actors. The analysis highlights how national and international discourses are at odds with local realities in ways which threaten to undermine both the aims of pursuing resilience and other broadly accepted imperatives such as equitably alleviating poverty. It is hoped this analysis will (1) contribute to the on-going challenge of increasing the legibility and coherence of national and international discourses on climate resilience with respect to local contexts, and vice-versa (Adger et al., 2001; Keeley and Scoones, 2000, 2004; Nyssen et al., 2004); and (2) aid efforts to ensure the responses to climate change do not have worse impacts than climate change itself (Marino and Ribot, 2012).

The paper is organised as follows. After describing the methods used in the study, section 3 contextualises the study by reviewing the background and evolution of Ethiopia's Climate Resilient Green Economy Strategy and outlining the case for addressing resilience in the coffee sector. Section 4 focuses on the principal state institutions associated with managing forests and coffee and the evolving structure of the coffee market and prevalent concerns regarding its functioning. Our analysis then, in section 5 , integrates this analysis with a critical review of the climate-coffee ecological literature and related emerging climate resilience strategies for the coffee sector. The paper concludes by reflecting on the general implications of the study.

\section{Methodology}

This study draws on mixed method fieldwork conducted in Ethiopia between December 2013 and October 2016. Specifically, the analysis draws on a series of 40 semi-structured interviews with purposively sampled key stakeholders in government agencies and non-governmental organisations across at National, Regional (Oromia Regional State), and District (Yayu and Dorani Woredas) levels. These geographic locations were selected due to their proximity to the Yayu Coffee Forest Biosphere Reserve, which was listed on the World Network of Biosphere Reserves by UNESCO in 2010 to protect coffee genetic resources contained within the reserve, and is a primary site of interest for coffee-forest management in Ethiopia. Individuals interviewed were selected to represent all of the key institutions concerned with managing the coffee-forest and the coffee sector in Ethiopia, including the Bureau of Agriculture and Natural Resources, Trade Bureau, Oromia Forest and Wildlife Enterprise (OFWE), Rural Land Administration, Oromia Environment, Forest and Climate Change Authority, the Ethiopian Biodiversity Institute (EBI), the Co-operative Promotion Agency, Oromia Coffee Farmers Co-operative Union and associated co-operatives, the Ethiopian Commodity Exchange, and Agricultural Development agents, local opinion leaders and senior Kabele ${ }^{1}$ officials. The interviews were designed to elicit the formal and informal responsibilities, activities and challenges of the key actors involved in governing the coffee-forest landscape and coffee sector at various levels. With six respondents photo elicitation was used to facilitate interviews (Clark-Ibáñez, 2004; Harper, 2002). This flexible design enabled respondents to shed light on both the formal and informal dynamics of the sector across levels and enabled deeper insights than more structured or narrow data collection methods permit.

These interviews were complemented at the local level with a series of additional interviews with coffee farmers ( $n=20$ ), focus groups ( $n=4,1$ male only participants, 1 female only participants and 2 with both male and female participants) and a household survey ( $n=240$; randomly sampled from 10 Kebeles, stratified by gender and wealth ranking). These methods, along with documentary and literature-based evidence are synthesised to inform the analysis of the emerging climate resilience strategies in section 5 . The analysis in this paper primarily employs qualitative methods, but also draws on the household survey data where relevant (Miles and Huberman, 1994; Punch, 2013).

\footnotetext{
${ }^{1}$ Kebeles, sometimes called peasant associations, are the smallest administrative unit of government in Ethiopia are constituted of several villages, known as gots.
} 


\section{Contextualising the Ethiopian case: Coffee and the Climate Resilient Green Economy}

Relative peace has characterised the rule of Ethiopian People's Revolutionary Democratic Front (EPRDF), an alliance of associated regional parties, since Derg leader Mengistu was disposed in 1991. The ensuing decades have seen considerable social and economic progress; the 2015 National Human Development Report identifies Ethiopia as among the countries with the highest absolute gains in conventional development indicators (UNDP, 2015). Furthermore, the economy has been among the five fastest growing economies globally having seen a GDP growth averaging $10.8 \%$ per annum between 2005-2015 (AFDB, 2015).

The historical dovetailing of environmental and political conditions in the country, manifest most famously in the 1983-1985 famine, has given the country's leaders an acute awareness of the potential for climate change to undermine contemporary progress and stability. As a result, Ethiopia outlined a vision for a Climate Resilient Green Economy (CRGE) and has developed a strategy for transforming the country into a carbon-neutral middle-income country by 2025 . The CRGE strategy is one among a suite of development policies (Fikreyesus et al., 2013) which aim to maintain economic growth by increasing the efficiency and intensity of agricultural production, adopt and promote advanced technologies to industrialise the economy and reduce pressure on land in rural areas, to access available climate finance by increasing carbon sequestration and deploy renewable and clean power generation (FDRE, 2011). Commitment to develop work on a CRGE have been further bolstered by the country's involvement with international climate change negotiations, including the Paris agreement which Ethiopia ratified in 2017.

Despite containing strategies to mitigate climate change, these are contingent on securing international financial support and efforts to mainstream the CRGE within the overarching Growth and Transformation Plan II suggests the predominant focus of the CRGE is on maintaining the resilience of the national economic growth to climate change. Although the importance of coffee is noted in the agriculture and forestry component of the CRGE strategy (FDRE, 2015), none of the 27 agricultural pilot projects implemented under the CRGE by 2016 included coffee, due ostensibly to a focus on food security ${ }^{2}$. Nonetheless, the coffee sector in Ethiopia holds high potential to be a key component of ongoing CRGE initiatives for three reasons.

First, the crop is vulnerable to climate change. Arabica coffee usually grows at altitudes between 1000-2000m in the moist Afromontane Forest ecosystem, (Gole, 2003; Gole et al., 2008; Senbeta and Denich, 2006)and, with increasing temperatures, rain-fed coffee production is likely to decline at lower elevations and there are finite areas of land at higher altitudes which limit the scope for the crop to migrate, potentially threatening coffee production (Davis et al., 2012). Second, the sector plays a key role in supporting the national economy and is a key source of foreign exchange earnings as well as supporting a quarter of the population ( 25 million people) directly and indirectly (Tefera, 2012). Thirdly, coffee can be key components of climate mitigation strategies, including Reducing Emissions From Deforestation and Degradation (REDD+) (Denu et al., 2016; Vanderhaegen et al., 2015). Whilst coffee has historically been a driver of forest degradation, it is also a model of forest conservation naturally an understorey forest plant and in Ethiopia is grown under varying levels of shade. The presence of coffee in landscapes therefore conserves forests (albeit in a degraded state) that might otherwise be cleared for other land use activities such as growing un-shaded crops such as chat (Chatha edulis), staple cereal crops like maize and livestock production (Aerts et al., 2011; Dessie and Kinlund, 2008; Getahun et al., 2013; Hylander and Nemomissa, 2008; Hylander et al., 2013). This means that the management of shade on coffee farms is an important component of

\footnotetext{
${ }^{2}$ Pers. Comms. Ministry of Agriculture - CGRE Unit representative (2016)
} 
forest management. Furthermore, increasing shade-levels on farms and establishing coffee forests on currently non-forested land could both buffer the crop against a warming climate and be eligible for carbon payments.

Discussions about improving the performance and governance of both the coffee and forestry sectors are ongoing. Understanding the implications of efforts to improve the climate resilience of the Ethiopian coffee sector, and promoting and implementing policies and laws which support the development of CRGE more generally, requires a detailed understanding of the governance arrangements of the sector, as addressed in the following section.

\section{Contextualising the pursuit of climate resilience - A critical overview of Ethiopia's coffee sector}

This section examines the governance of the coffee sector according to the roles of the state and market and serves to situate a critical discussion of strategies to promote climate resilience in the sector in Section 5.

\subsection{State institutions for coffee-forest management}

Until recently, the Ministry of Agriculture and Natural Resource ${ }^{3}$ (MoANR) was responsible for overseeing and supporting the production of coffee on the farm, and the Ministry of Trade (MoT) in collaboration with Co-operative Promotion Agency co-ordinated the coffee market from the farm gate. The newly (2016) re-established Coffee and Tea Development and Marketing Authority now regulates the entire sector and is now responsible for both the production and trade of coffee.

The centrepiece of government involvement with the sector at the farm level is the provision of agricultural extension. This is delivered by Agricultural Development Agents (DA), usually three per Kebele. In the area surrounding Yayu, and elsewhere in the country, the DAs organise farmers into groups of 20 or 30 individuals. The designated head of these groups, called Garemisoma, train subgroups known as Tokoshane $e^{4}$. Tokoshane is an old Oromo mode of social organisation, it refers to groups of $\sim 5$ people who mutually support each other and is currently going through a period of revival in parts of Ethiopia with leaders at all levels of government also adopting the practice. It is through this system of extension, combined with grassroots administrative and party structures coordinated through the Kebele and Woreda (district) leadership that, as Berhanu and Poulton (2014) put it 'make scrutiny and control of activities down to the household level increasingly complete'.

The widespread provision of extension is illustrated by data from the household survey; more than a third of respondents see a DA once a week or more often and $75 \%$ see DAs at least 3 times per year. However, in interviews and focus groups with farmers it was noted that coffee was generally not the subject of extension and the expertise of DAs was in non-coffee crops. This was perceived by some regional and sub-regional level decision-makers to reflect a general neglect of the coffee sector at a federal level, largely underpinned by the national focus on food security and the production of food crops.

Although the MoANR dominates the governance of the coffee sector, there are several other important institutions, particularly in the climate resilience context. First, the responsibility for managing Oromia's forest estate currently lies with the Oromia Forest and Wildlife Enterprise (OFWE). This is important because the distinction between forest and farmland in coffee systems is often arbitrary. There is a continuum between coffee grown under low shade (often referred to as

\footnotetext{
${ }^{3}$ Previously Ministry of Agriculture

${ }^{4}$ Literally translated as one in five
} 
garden coffee) to coffee harvested from naturally occurring plants in largely intact forest areas (known as wild coffee), although the very low fruiting densities of coffee in intact forests (due to high shading and low density of coffee shrubs) make harvesting genuinely 'wild forest' coffee unviable. In general, the focus of the OFWE has been to establish and manage timber plantations. Protecting natural forests is also under the mandate of the OFWE but has been neglected, according to interview respondents, because it does not deliver tangible financial benefits to the self-funded organisation. However, the benefits of preserving coffee genetic resources in situ (Aerts et al., 2017), typified by the institution of the Yayu UNESCO Coffee-Forest Biosphere Reserve, and the carbon stored in forests are both potentially resources which could be monetised, for example, through REDD+ mechanisms or coffee marketing schemes ${ }^{5}$. The prospect of financial benefits flowing from forest conservation has highlighted a degree of 'fuzziness' around the limits of the OFWE's mandate and capacity. The creation of a new Ministry of Environment, Forestry and Climate Change (MEFCC) to host REDD+ secretariat activities has not ameliorated institutional contestation over responsibility for managing forests, and has plausibly exacerbated the issue. The importance and experience within the Ministry of Agriculture and Natural Resources in managing trees on coffee farms, ongoing establishment of plantations through its watershed management programme and historical management of forest reserves, for example, gives it a key role in supporting the development of climate resilient coffee.

In Oromia region, the Oromia Environment, Forest and Climate Change Authority (OEFCCA) (previously Rural Land Administration and Environmental Protection bureau), has also historically been responsible for regulating landscape level decision-making, including the granting of permission to undertake particular agricultural activities in particularly places, and prohibiting others elsewhere. During an interview with a district officer for the OEFCCA, the difficulties associated with landscape management were elucidated:

'At Woreda level we have 3 core process areas: Land Administration; Land-use Planning; and Environmental Protection... But the attention given to this office however is very low, we have no power and limited budget for logistics. The mandate to do land-use planning is given to this office, but agriculture say it is for them. They are planning for soil and water conservation, and micro-catchment treatments. The mandates overlap. But agriculture bureau has manpower, it has logistics, it has money and it has power. Regarding forests it remains unclear. Agriculture say that the patch forests belong to them, EFCC say we have to regulate forests and deforestation, which trees are planted, which trees are removed and OFWE say, all the forest areas belong to me. But practically, they (forests) have no owner.'

They continued:

'It would be better to synthesise mandates and discuss together. It needs training and manpower as well. For example all the offices are coming to us to ask for data for collecting revenue, tax, for land planning to see who has what. But all we have is this big book to document our data, we don't have PCs, we don't have power and so we cannot make it electronic. We do it manually every time.'

The practical and bureaucratic challenges associated with managing trees, coffee and land within complex landscapes are difficult to reconcile with the technical, straightforward, clean provisions laid out in central planning documents such as the CRGE strategy ${ }^{6}$. Recognition of the difficulties

\footnotetext{
${ }^{5}$ See, for example, nascent work on climate-smart coffee by organisations such as Forest Trends, Farm Africa and Solidaridad.

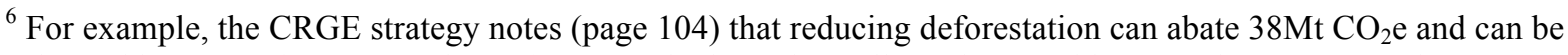
achieved by intensifying agriculture, for example through small, medium and large-scale irrigation schemes.
} 
associated with a dominant agricultural ministry and overlapping mandates between institutions, was partly behind the Federal Government's commitment to re-establishing the state-based Tea and Coffee Marketing and Development Authority to regulate the entire coffee sector from farm to market (Fortune, 2015). Details of exactly how the financial and human resources involved in providing extension, co-ordinating land-use planning (including with respect to forests) and regulating and developing the market will be divided are still under discussion? ${ }^{7}$.

\subsection{Structure and challenges of the Ethiopian coffee market}

This section examines the 2 streams of coffee marketing in Ethiopia the Ethiopian Commodity Exchange (ECX; see Figure 1) and the co-operative structure; which are co-ordinated and regulated by the state through the Ministry of Trade and Co-operative Promotion Agency respectively. This analysis is important for climate resilience considerations for two reasons. At a national and regional levels, the profitability of the coffee sector has significant influence on the country's financial capacity to invest in resilience enhancing strategies, for example of value-chain infrastructure in the coffee sector and investments in job creating activities in non-coffee sectors. At a local level, income is a critical resource for households buffering climate and other shocks and for investing in climate resilience farm management practices such as irrigation. Furthermore, local profitability of coffee will, to a large extent, dictate the scale of conversion between shaded coffee and unshaded Chat.

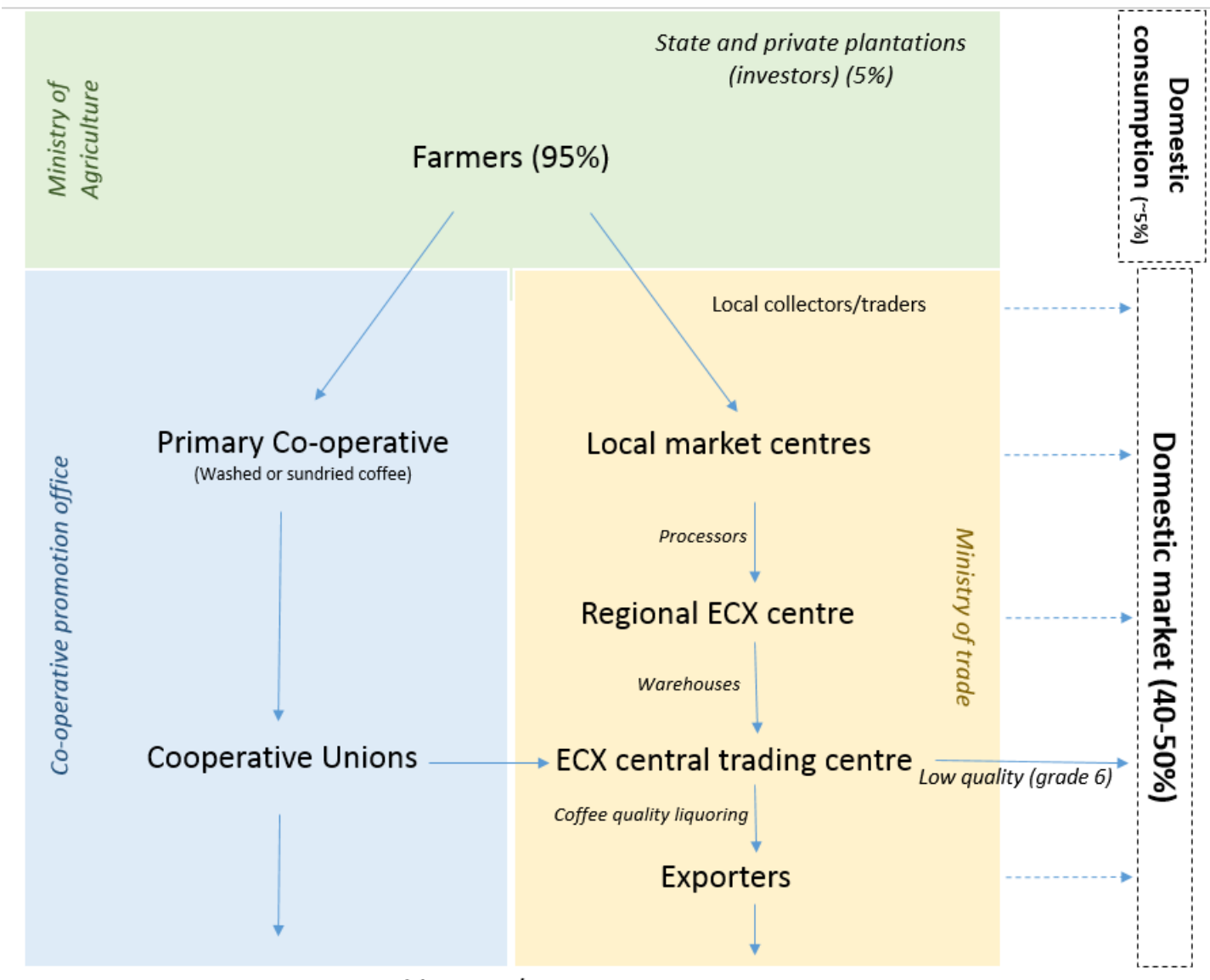

International buyers/roasting companies

Figure 1. Schematic of coffee marketing chain in Ethiopia. Principal regulatory bodies are represented by coloured boxes. Percentages refer to proportions of production.

\footnotetext{
${ }^{7}$ As noted by a government respondent
} 
The Ethiopian Commodity Exchange (ECX) is a private-public enterprise established in 2008 in response to concerns regarding markets for products such as coffee, low market penetration into rural areas, high transaction costs, and risks associated with a lack of quality assurance particularly prevalent. Coffee is sold into local markets in small towns such as Yayu, where the price is fixed relative to prices in national and international markets (i.e. the price cannot be negotiated between farmers and traders), and then transported to regional ECX centres where it is graded for quality, and then stored in the Addis Ababa warehouse before export (Gelaw, et al. 2017).

In addition to selling coffee into the ECX system, farmers can join co-operatives and sell their coffee there. Co-operatives are licenced and regulated by the Co-operative Promotion Agency and organised into collectives, known as Co-operative Unions, the largest of which is the Oromia Coffee Farmers Co-operative Union. Unions can sell coffee through the ECX or export directly. Cooperatives are highly promoted by the government in Ethiopia because the co-ordination of farmers can deliver benefits in terms of navigating market fluctuations. They have also been the sites for large Technoserve ${ }^{8}$ assisted projects installing wet processing units ${ }^{9}$ in coffee growing regions. Of particular importance for climate resilience, co-operatives also facilitate access to certified markets, such as Fairtrade, Organic or Rainforest Alliance as well as speciality single-origin buyers. In theory, these schemes could increase farmer resilience by increasing incomes, and in the case of Rainforest Alliance, for example, also support the retention of shade tree contributing to climate mitigation.

The binary distinction between coffee marketing through the ECX or co-operatives does not, however, accurately reflect how farmers' engage with the coffee market and masks local complexities. Surveyed farmers who were members of co-operatives cited better access to products, markets and credit as the three most important benefits of membership. However, only $26 \%$ of farmers belonged to a coffee co-operative in our study area. The most cited reasons given for nonmembership were a perceived poor management and corruption (42\%), not being able to afford the membership fee (37\%) and a lack of co-operatives in the local area (8\%). This reflects two primary difficulties. First, farmers receive a small payment when they deliver their coffee to the co-operative (average $6 \mathrm{birr} / \mathrm{kg}$ red cherry during 2015 harvest $^{10}$ ) and then receive a dividend (a share of the profits which is shared between the Union, the Co-operative and the members) once the coffee is sold. The non-payment of the dividend, sometimes because the dividend is used to service debts incurred when purchasing a wet processing machine, frustrates farmers and undermines trust in the co-operatives. Interview respondents also suggested that the historical association of co-operatives with obligatory collective labour under the Derg regime further discourages some farmers from joining co-operatives.

Unsurprisingly, most farmers prefer to sell their coffee, via local coffee traders known as $a k r a b i^{11}$, through the ECX, where prices fluctuate according to international market conditions. During the 2015 harvest the price in the local market in Yayu was between 2 and 7 times higher $^{12}$ than the average price at co-operatives at harvest time, with the local market price (set through the ECX)

\footnotetext{
${ }^{8}$ An organisation promoting business solutions to poverty.

${ }^{9}$ Wet processing requires fresh coffee beans $(<24$ hours since picking) and delivers a more uniform and predictable flavour compared to dry processed beans which are air dried before hulling. Wet processed coffee is desirable for many exporters, but the unique and distinctive flavours that dry processing can deliver are growing in popularity among increasingly discerning consumers and the companies providing speciality coffee to the market.

${ }^{10}$ The price in the ECX market during the time of this research was $23-26$ birr $/ \mathrm{kg}$.

${ }^{11}$ Who may also facilitate the trading of coffee between farmers and co-operatives.

${ }^{12}$ Although prices across marketing streams are not directly comparable because farmers can sell either fresh red cherries or dried coffee cherries and some quoted prices refer to hulled coffee, with significant weight differences along the processing chain. Nonetheless, farmers reporting receiving considerable higher prices for coffee in the market than the initial price received in the co-operatives.
} 
increasing through the year (as local supply declines in the period after peak harvest) which generally benefits farmers who can afford to delay sales and store their coffee. Farmers, government officials and co-operative managers also complain about traders buying coffee significantly below the set price or intercepting farmers on the way to sell their coffee to the co-operatives and offering them a higher (pre-dividend) price. Furthermore, government representatives said that the strong domestic market for coffee in the country ${ }^{13}$ means that prices are often higher in local markets than in international markets. Although interview respondents recognised the benefit this delivers to farmers during times of low international prices, in an effort to maximise foreign exchange the government has criminalised the sale of export grade coffee domestically. Inevitably coffee leaks out of the formal market at every stage. These findings are important to the pursuit of climate resilience because it highlights the challenges associated with market-based strategies for enhancing farmer incomes or, through certification, addressing farm management strategies (see section 5.2).

Local traders, some of whom are also coffee farmers, were also widely criticised among local authorities for undermining the quality of coffee since they will collect coffee in any container and do not ensure coffee is processed well or stored and transported in jute ${ }^{14}$ bags. Numerous interview respondents in regulatory positions suggested these practices are compounded by farmers indiscriminately picking green and red cherries together rather than focusing on ripe red cherries with higher sugar content. However, the problem with low quality is more systemic than the narrative of illegal traders and ignorant farmers, frequently put forward by local government officials, suggests. First, there is ineffective price differentiation for quality in local markets and therefore no incentive for farmers to invest extra time and money, for labour and materials, to produce extra high quality coffee. Even in local ECX trading centres coffee is simply visually inspected and given a grade between 1 and $3^{15}$, with the price increasing by only $1 \mathrm{birr} / \mathrm{kg}$ for each grade. Farmers reported that this level of differentiation, which represents $4-6 \%$ of the price received, is insufficient to incentivise quality production or compensate for additional costs. Second, jute, and other processing materials that facilitate high quality post harvesting processing such as chicken wire, bamboo for drying bed and plastic for covering, are not available on the open market in Yayu and are unavailable to the majority of farmers. Such items are generally only available through cooperatives, NGOs or farmers with large land-holdings, who acquire them from Addis Ababa.

One local trader in the Yayu market centre summarised the challenge:

'We try for quality but the difference once you get to Bedele is only 10 birr for each $17 \mathrm{~kg}$ bag... So why bother for quality? It is labour and time consuming to ensure quality, it is a big problem... We are also trying to make the farmer aware, but why should they bother since the price difference is so low. Once there is not quality here, or on the farm, then you cannot make it better anywhere else.'

The existing state of Ethiopia's coffee sector is the context in which efforts to address climate resilient coffee are situated. Appreciating the sector specific context frames and underpins the subsequent analysis which critically examines proposals raised in the literature and among policymakers in Ethiopia to address climate resilience in the coffee sector. In particular, it contrasts

\footnotetext{
${ }^{13}$ Approximately $40-50 \%$ of coffee produced in the country is consumed domestically.

${ }^{14}$ Jute is a natural fibre which does not affect the quality or flavour of coffee which is hydroscopic so sensitive to mis-management. Especially common detrimental practices include drying coffee on the floor (earthy) and storing in plastic bags, often fertiliser bags.

${ }^{15}$ At a national level, coffee is graded from 1-6, with grades 1-5 being exported and the others being sold on the domestic market. Proclamation 602/2008 subsection 14(5) prohibits the sale of export grade coffee in the domestic market.
} 
proposals originating from national and international institutions with local levels actors' perspectives on the context in which they operate.

\section{Critical reflections on pursuing climate resilient coffee in Ethiopia}

This section draws on and extends the analysis above to critically reflect on prospects and policypriorities for pursuing climate resilient coffee in Ethiopia. In particular, it demonstrates how taking stock of the wider dynamics of the sector highlights often overlooked constraints and trade-offs climate resilience strategies entail. It reflects on how policies, ostensibly rooted in concern for sustainable coffee productivity might exacerbate other concerns regarding poverty and equality. The discussion focuses on 3 key issues: spatial responses, farm productivity, and the development and use of improved varieties based on the use of Ethiopia's coffee genetic resources. Wider sectoral issues, such as profitability of the sector at farm and national level and developing market linkages are not addressed here in order to focus on the issues which link most closely with the ecology of the coffee.

\subsection{Spatial response}

One response to studies which map the spatial shifts of suitable climatic envelopes for coffee (Davis et al., 2012; Moat et al., 2017; Ovalle-Rivera et al., 2015) involves the migration of coffee, and may therefore, also involve people changing livelihood practices or migrating away from areas of decreasing climatic suitability and, if opportunities exist, into suitable areas. This challenge intersects with national-level planning in the sector, a key component of which entails balancing the promotion of large-scale investments in plantations with small-holder production. A representative from the Ministry of Agriculture and Natural Resources stated how they were becoming 'hesitant' to support coffee in low lying areas and were looking to establish plantations, as opposed to small-holder farms, on higher lands. Large-scale investments required to develop plantations are a sensitive issue in the Ethiopian context where the dynamics of ethnic-federalism and state ownership of land cause consternation over the prospect of displacements (Rahmato, 2014), ethnic self-determination (Lavers, 2012) and local citizen participation in decision-making (Guillozet, 2014). The challenge facing policy-makers is how to foster the most appropriate enabling environment for migrations which maximise the benefits from the coffee sector without unduly infringing on farmer's freedoms.

The creation of maps, such as Ethiopia's coffee atlas (Davis et al., 2017), is not merely a technical cartographic exercise but influences relationships of power (Crampton, 2001; Harley, 2009), and in the case of Ethiopia could augment centralised top-down governance. For example, Ethiopia's Investment Commission 2015 guide states that 600,000 hectares of land is currently under coffee cultivation. It also says 426,000 hectares of land are available for coffee plantations and 'there is strong commitment from government to avail the country's fertile land for investment'. Since all land in Ethiopia is owned by the state, large-scale investments in coffee plantations often involves renting land from the state in order to 'rejuvenate' existing farms. Identifying suitable areas for directing investments is potentially more effective with scientific knowledge, however, such tools can also be used to support decisions which have profound social implications.

At a local level, land-use planning in coffee farming areas is ostensibly the responsibility of the Environment, Forest and Climate Change Authority, but in reality it is divided between institutions and there is a discontent among local government officials concerning the capacity to create and implement robust plans, with few working computers and no GPS receivers in either the Yayu or Dorani Woredas. Furthermore, interview respondents argued that Kebele leaders hold considerable 
de facto power over the distribution of land at a local level. The contrast between spatial planning practices and narratives at (inter)national and local levels is stark.

The point here is not to undermine the critical contribution and utility of scientific research on climate change adaptation on the national level, but to highlight how the governance responses to ecological research and cartography may clash with the values of the individuals and funding agencies which undertake such research. Given the increasing certainty regarding the spatial response of coffee to climate change, it is important to begin to develop the strategies for supporting farmers who may be in areas where coffee may stressed as a result of climate change and for farmers who currently live in areas that may become suitable for farming coffee. This includes potentially challenging questions regarding the trade-offs involved in promoting large-scale investments in the sector relative to support to small-holders. For scientists to support decisionmaking in this area, it is important that the processes that determine how knowledge about the impacts of climate change is transformed across scales, used by different actors and influences the evolution of relevant policy agendas.

\subsection{Addressing farm productivity - shade as exemplar}

While climate change may initiate a spatial response in coffee production, it may also necessitate changes to farm management practices such as mulching, irrigation, and shade management to remain productive. Shade cover is particularly important since it regulates flowering and microclimatic conditions such as humidity and temperature (Cannell, 1985; Carr, 2001). The importance of shade management under a changing climate is likely to grow in importance because appropriate shading may buffer the adverse effects of rising temperatures and declining water availability which stresses plants and makes them more susceptible to disease (Beer et al. 1998). For example, Lin (2007) shows that important climatic variables such as temperature, humidity, solar radiation and soil moisture fluctuate more as shade decreases. As such, shade can mitigate against micro-climatic extremes that are likely to become more prevalent in a changing climate. However, the interactions between climate, shade level and shade tree diversity, landscape characteristics (for example size and diversity of adjacent forest patches), elevation, irrigation, pests and disease dynamics are complex (e.g. López-Bravo et al. 2012). Field studies assessing the impacts of shade on coffee productivity and their interactions with these factors are limited. But there is evidence to suggest the relationship between shade and rain-fed coffee production is hump-shaped, with productivity limited by high or low shade cover (Perfecto and Vandermeer, 2015; Perfecto et al., 2005; Soto-Pinto et al., 2000). This suggesst that identifying and pursuing an optimum level of shade will be a key part of the agronomic component of a climate resilient coffee strategy.

However, even where ecologically based knowledge concerning the optimum forest management practices exists, there is evidence to suggest this might not easily translate into actual changes in management. A brief review of the current governance arrangements concerning trees on coffee farms highlights how recommended practices for forest and biodiversity conservation are part of a wider landscape of contestations concerning who controls natural resources and how. This raises important questions for how effective shade management recommendations will be and highlights how institutional changes instigated in light of ecological knowledge can undermine farmer's control over their farms and resources, potentially to the detriment of their resilience.

Awareness of the importance of shade for coffee farms is high and the practice of planting trees for timber is widespread which means that shade in coffee farms is relatively high around Yayu. Nevertheless, Kebele leaders and DAs, who are required to give formal permission to farmers to fell trees, complain that they had relatively little control over farmers' decisions about tree management. Participants in the photo elicitation interviews highlighted how farmers avoid formal 
processes and maintain control over the trees on their farms by practicing ring-barking ${ }^{16}$ so that they 'die of natural causes' and therefore are not violating the law, under which tree felling is prohibited. As a result, shade levels generally reflect farmers' best judgement about the level of shade which maximises production within the constraints of existing tree stocks on the farm, the availability of saplings for favoured species ${ }^{17}$ and the use of trees for other purposes such as timber or hosting bee hives.

Conceivably, if ecologists show that there is an optimum shade level and this is mandated for farms under a climate resilient coffee strategy, without due recourse for local expert farmer knowledge and decision making, this could in theory exacerbate the criminalisation of farmers felling trees without permission, and further widen the opportunities for rent-seeking at a local level (Putzel et al., 2015). Extension programs that dictate management practices may further undermine farmers' control over their farms and livelihoods with consequential implications for equity and wellbeing. Clearly, there is a need for research into optimal shade management in coffee systems in Ethiopia to integrate ecological insights with the institutional arrangements that enable and constrain farmers' decisions and account for the range of objectives that farmers might be interested in pursuing in addition to growing coffee. Such interdisciplinary approaches are required to mitigate the risk that excessively simplistic solutions to complex problems are promoted, often in the interests of researchers who are increasingly incentivised to maximise the 'impact' of their research (Martin, 2011).

\subsection{Developing climate resilient varieties}

A critical component of climate resilience in the coffee sector is developing coffee varieties which are resistant to drought without compromising on yield, quality and resistance to pests and diseases (van der Vossen et al., 2015). The ability to develop these characteristics is dependent on conserving and utilising existing genetic resources, most of which is contained in the forests of Ethiopia (Labouisse et al., 2008; Mehrabi and Lashermes, 2017). It is widely agreed that conserving and accessing Ethiopia's genetic resources is critical to advancing variety development, particularly with respect to maintaining quality in drought tolerant varieties that perform well under variable environments (Gole et al., 2002; Mehrabi and Lashermes, 2017; van der Vossen et al., 2015; Vlek, 2001). However, as this section explores, there are contestations concerning the distribution of costs and benefits associated with the work required to conserve genetic resources and develop improved varieties.

Ethiopia's accession to the Nagoya protocol, under the UN Convention on Biological Diversity, has helped stimulate the establishment of 5 new ex situ gene banks (FDRE, 2014). However, representatives from the Ethiopian Biodiversity Institute suggested that the chances of reaching agreement on access and benefit sharing (ABS) seem remote. Efforts to economically value Ethiopia's coffee genetic resource have highlighted the importance of the issue, but the uncertainties involved means that estimates have a wide range, between 420 and 1458 million US\$ (Hein and Gatzweiler, 2006). Such estimates, while potentially appealing, do little to clarify negotiations on access and benefit sharing. Furthermore, despite significant progress being made concerning in situ conservation with the establishment of UNESCO Man and Biosphere reserves in Kafa and Yayu, there concerns remain regarding protection and utilisation of Ethiopian coffee genetic resources (Aerts et al., 2017; Mehrabi and Lashermes, 2017). The selection of the Yayu area as the site of a new coal-mine and fertilizer complex (Tadesse, 2015) raises serious questions regarding state commitment to coffee genetic resource conservation in the area and, inevitably, has become a point of conflict.

\footnotetext{
${ }^{16}$ Remove a strip of bark around the circumference of a tree to kill it.

${ }^{17}$ Highly preferred species include: Alibizia schimperiana, Cordia Africana and Millettia ferruginea
} 
Such contestations around the conservation of genetic resources are generally side-lined in academic literature in favour of technical considerations or generic concerns regarding institutional capacity and coordination, potentially because of the sensitivities concerning the details of institutional conflicts, particularly across the Federal-Regional boundary. One respondent from the Ethiopian Biodiversity Institute (EBI) admitted that some of the conflict regarding responsibility for managing Yayu biosphere reserve revolved around accessing funding:

'The EBI used to be accountable to MoA [Ministry of Agriculture], but now it is under MEFCC [Ministry of Environment, Forestry and Climate Change], although there is still some debate whether it should be accountable to Ministry of Science and Technology [MST]. They [MST] think they should administer the reserve. The debate is ongoing. There is a rumour that a lot of donor money is coming and that is why they cannot agree.'

Although individual conflicts such as this are usually resolved, this quote illustrates concerns regarding a general pattern of continual institutional reform in response to external opportunities and challenges. This incessant reform poses challenges to developing continuous and coherent strategies with respect to genetic resource management.

Incentivising conservation and development of Ethiopia's coffee genetic resources is at an impasse. Ethiopia is justifiably protective over its genetic resources, which have historically been viewed as 'gifts' to the world. In accordance with international agreements (Hein and Gatzweiler, 2006), Ethiopia contends that private access to genetic resources should be adequately compensated. However, there are major debates concerning who should pay compensation. Debates concerning access to, and value of, coffee genetic resources combined with the wider context such as the recent state of emergency (BBC, 2016a, b) undermines the case for private investment in research and development, a key conditionality on compensating protection of genetic resources. Calls for cooperation on the protection and utilisation of genetic resources to be restricted to 'precompetitive' stages of Arabica coffee breeding (such as application of genetic and genomic technologies, sharing of scientific information and pre-breeding for specific characters) (van der Vossen et al., 2015) may be unrealistic given the dynamics of discontent which are rooted in real and perceived injustices concerning the internationally unequal distribution of benefits associated with the utilisation of Ethiopian coffee genetic resources.

One senior official from the Ministry of Science and Technology highlighted significant concerns the government has about genetic materials (including coffee and teff) being smuggled out of the country. He went to say that 'the community had protected and nurtured the resource for hundreds if not thousands of years and so their role in that should be recognised, they should benefit. We went for a meeting in the Netherlands to discuss compensation but we could not come to agreement.' There is an impasse; industry will not pay for conserving and developing coffee genetic resources with no prospect of return on investment, and the Ethiopian government does not want to risk missing out on further benefits derived from coffee. Evidently, the role of the international community and donors in navigating contestations around the relative value of genetic resources, their management and the use of compensation is critical.

\section{Concluding remarks}

Adopting a critical lens to examine the pursuit of a climate resilient coffee sector in Ethiopia highlights the complexity of the challenge facing policy-makers. The analysis presented in this paper raises three important questions. The first concerns how ecological knowledge is transformed across 
scales and utilised by national states, international companies and communities directly impacted by climate change. The challenges facing farmers are manifold, and unravelling the relative impact of climate change on coffee farms remains extremely challenging. The complexity of this impact is reduced at the national and international level, where discussions idealise institutional and social dynamics. For example, the spatial (elevation), social (farmer interests, institutions and management strategies) and ecological (e.g. disease) interactions concerning coffee production under different shade regimes (see Sections 5.1 and 5.2) are not captured by maps produced from ecological niche modelling. As a result, policy discussions risk becoming cleaved away from the context in which farmers operate and other challenges they face. Such a risk is manifest in the relatively superficial treatment of the coffee sector in the CRGE. A deeper understanding of the context and mechanisms driving individual and sectoral decision-making facilitated by studies such as these, and others that examined the science-policy interface, provides a basis for a more robust engagement with climate resilience policy development.

The second question raised by this analysis involves determining how the transformation of climate change knowledge and impacts across scales influences the evolution of the policy-agenda.

Understanding how high-level elites, policy-makers and the donors which support them helps to understand the creation, use and integration of ecological knowledge with other relevant bodies of knowledge concerning the coffee sector is essential to examining how particular actions and policycourses become legitimate. Although the rhetoric of climate resilience is rich in win-wins, the analysis presented here highlights how the impacts of climate change on coffee are socially as well as spatially disaggregated. And therefore, it is important to begin developing strategies for enabling farmers who currently do not farm coffee to maximise the opportunities that may emerge and minimising the disruptive impacts of climate change in areas and segments of populations that will be negatively impacted. There are also potential trade-offs between supporting large-scale investments in establishing new coffee areas and supporting new small-holder farmers in coffee farming.

Thirdly, given that research may illuminate but not resolve complex trade-offs, it is important to question extent to which social and natural scientists and those that fund their work in contexts like Ethiopia should be responsible for the use and impacts of their research and the decisions of those who might use scientific research to legitimise particular courses of action. The growing importance of the 'impact' agenda in UK research institutions, and elsewhere, urgently needs to address this question. Currently, the incentives encourage high-profile use of science without requisite normative reflection on the influence of high-profile uses of science in developing country contexts might have, albeit unintentionally, in entrenching existing patterns of social relations. It is imperative that the donors funding research and the researchers they support develop climate resilience activities that are grounded in an understanding of the complex realities of the countries in which they are operating.

\section{Acknowledgements}

The authors thank all the participants for their generosity in sharing their experiences and knowledge. They also appreciate insightful discussions with other members of the ECOLIMITS research team and members of the ecosystem governance group at the Environmental Change Institute (ECI), University of Oxford. This work was funded through the Ecosystem Services for Poverty Alleviation (ESPA) programme (Project Code NE/K010379-1) funded by the Department for International Development (DFID), the Economic and Social Research Council (ESRC) and the Natural Environment Research Council (NERC). 


\section{References}

Adger, W.N. (2000) Social and ecological resilience: are they related? Progress in Human Geography 24, 347-364.

Adger, W.N., Benjaminsen, T.A., Brown, K., Svarstad, H. (2001) Advancing a political ecology of global environmental discourses. Development and change 32, 681-715.

Aerts, R., Geeraert, L., Berecha, G., Hundera, K., Muys, B., De Kort, H., Honnay, O. (2017) Conserving wild Arabica coffee: Emerging threats and opportunities. Agriculture, Ecosystems \& Environment 237, 75-79.

Aerts, R., Hundera, K., Berecha, G., Gijbels, P., Baeten, M., Van Mechelen, M., Hermy, M., Muys, B., Honnay, O. (2011) Semi-forest coffee cultivation and the conservation of Ethiopian Afromontane rainforest fragments. Forest Ecology and Management 261, 1034-1041.

AFDB, (2015) Ethiopia Economic Outlook. African Development Bank Group.

Anthony, F., Combes, M., Astorga, C., Bertrand, B., Graziosi, G., Lashermes, P. (2002) The origin of cultivated Coffea arabica L. varieties revealed by AFLP and SSR markers. Theoretical and Applied Genetics 104, 894-900.

Arslan, A., Reicher, C.P. (2011) The Effects of the Coffee Trademarking Initiative and Starbucks Publicity on Export Prices of Ethiopian Coffee. Journal of African Economies.

BBC, (2016a) Ethiopia declares state of emergency amid protests.

BBC, (2016b) Ethiopia mourns 55 killed during protest at Oromia festival.

Beer, J., Muschler, R., Kass, D., \& Somarriba, E. (1997). Shade management in coffee and cacao plantations. Agroforestry systems, 38(1-3), 139-164.

Berhanu, K., Poulton, C. (2014) The political economy of agricultural extension policy in Ethiopia: economic growth and political control. Development Policy Review 32, s199-s216.

Bunn, C., Läderach, P., Rivera, O.O., Kirschke, D. (2015) A bitter cup: climate change profile of global production of Arabica and Robusta coffee. Climatic Change 129, 89-101.

Cannell, M., (1985) Physiology of the coffee crop, Coffee. Springer, pp. 108-134.

Carr, M. (2001) The water relations and irrigation requirements of coffee. Experimental Agriculture 37, 1-36.

Christopher Brown, J., Purcell, M. (2005) There's nothing inherent about scale: political ecology, the local trap, and the politics of development in the Brazilian Amazon. Geoforum 36, 607-624.

Clark-Ibáñez, M. (2004). Framing the social world with photo-elicitation interviews. American behavioral scientist, 47(12), 1507-1527.

Crampton, J.W. (2001) Maps as social constructions: power, communication and visualization.

Progress in Human Geography 25, 235-252.

Daviron, B., Ponte, S. (2005) The coffee paradox: Global markets, commodity trade and the elusive promise of development. Zed books.

Davis, A., Moat, J., Wilkinson, T. (2017) Coffee Atlas of Ethiopia. Royal Botanic Gardens Kew, London.

Davis, A.P., Gole, T.W., Baena, S., Moat, J. (2012) The impact of climate change on indigenous arabica coffee (Coffea arabica): predicting future trends and identifying priorities. PloS one 7 , e47981.

Denu, D., Platts, P.J., Kelbessa, E., Gole, T.W., Marchant, R. (2016) The role of traditional coffee management in forest conservation and carbon storage in the Jimma Highlands, Ethiopia. Forests, Trees and Livelihoods 25, 226-238.

Dessie, G., Kinlund, P. (2008) KHAT EXPANSION AND FOREST DECLINE IN WONDO GENET, ETHIOPIA. Geografiska Annaler: Series B, Human Geography 90, 187-203.

EEA, (2015) Report on the Ethiopian Economy. Ethiopian Economics Association, Addis Ababa.

FDRE, (2011) Ethiopia's Climate Resilient Green Economy: Green Economy Strategy, FDRE. Federal Democratic Republic of Ethiopia, Addis Ababa: . 
FDRE, (2014) Ethiopia's Fifth National Report to the Convention on Biological Diversity, in: Institute, E.B. (Ed.). FEDERAL DEMOCRATIC REPUBLIC OF ETHIOPIA, Addis Ababa.

FDRE, (2015) Ethiopia's Climate Resilient Green Economy: CLIMATE RESILIENCE STRATEGY

AGRICULTURE AND FORESTRY. Federal Democratic Republic of the Ethiopia, Addis Ababa.

Fikreyesus, D., Kaur, N., Kallore, M., Ayalew, L., (2013) Public Policy Responses for a Climate Resilient Green Economy in Ethiopia, IIED Research Report. International Institute of Environment and Development, London.

Folke, C. (2006) Resilience: The emergence of a perspective for social-ecological systems analyses. Global Environmental Change 16, 253-267.

Folke, C., Hahn, T., Olsson, P., Norberg, J. (2005) Adaptive governance of social-ecological systems. Annu. Rev. Environ. Resour. 30, 441-473.

Forsyth, T. (2001) Critical realism and political ecology.

Forsyth, T. (2008) Political ecology and the epistemology of social justice. Geoforum 39, 756-764.

Fortune, A., (2015) Ministry of Agriculture to Re-Establish Coffee \& Tea Authority.

Gelaw, F., Speelman, S., \& Huylenbroeck, G. (2017). Impacts of Institutional Intervention on Price

Transmissions: The Case of the Ethiopian Commodity Exchange. Review of Development

Economics, 21(4).

Getahun, K., Van Rompaey, A., Van Turnhout, P., Poesen, J. (2013) Factors controlling patterns of deforestation in moist evergreen Afromontane forests of Southwest Ethiopia. Forest Ecology and Management 304, 171-181.

Gole, T.W. (2003) Vegetation of the Yayu forest in SW Ethiopia: impacts of human use and implications for in situ conservation of wild Coffea arabica L. populations. Cuvillier.

Gole, T.W., Borsch, T., Denich, M., Teketay, D. (2008) Floristic composition and environmental factors characterizing coffee forests in southwest Ethiopia. Forest Ecology and Management 255, 2138-2150.

Gole, T.W., Denich, M., Teketay, D., Vlek, P., (2002) Human Impacts on the Coffea arabica Genepool in Ethiopia and the Need for its in-situ Conservation, in: Engels, J.M.M., Rao Ramanatha, V., Brown, A.H.D., Jackson, M.T. (Eds.), Managing plant genetic diversity. CABI Pub, International Plant Genetic Resources Institute (IPGRI), Rome.

Görg, C. (2007) Landscape governance: The "politics of scale" and the "natural" conditions of places. Geoforum 38, 954-966.

Green, K.E. (2016) A political ecology of scaling: Struggles over power, land and authority. Geoforum 74, 88-97.

Guillaumet, J., Hallé, F. (1967) Etude de la variabilité du Coffea arabica dans son aire d'origine.

Rapport sur la mission ORSTOM dans le Sud-Ouest de l'Ethiopie 12.

Guillozet, K. (2014) Forest investments and channels of contestation in highland Ethiopia. African Identities 12, 45-61.

Harley, J.B. (2009) Maps, knowledge, and power. Geographic Thought-A praxis perspective.

Harper, D. (2002). Talking about pictures: A case for photo elicitation. Visual studies, 17(1), 13-26.

Hein, L., Gatzweiler, F. (2006) The economic value of coffee (Coffea arabica) genetic resources. Ecological Economics 60, 176-185.

Hylander, K., Nemomissa, S. (2008) Home garden coffee as a repository of epiphyte biodiversity in Ethiopia. Frontiers in Ecology and the Environment 6, 524-528.

Hylander, K., Nemomissa, S., Delrue, J., Enkosa, W. (2013) Effects of Coffee Management on

Deforestation Rates and Forest Integrity. Conservation biology 27, 1031-1040.

ICO, (2016) Total production by all exporting countries. International Coffee Organisation. Jaramillo, J., Chabi-Olaye, A., Kamonjo, C., Jaramillo, A., Vega, F.E., Poehling, H.-M., Borgemeister, C. (2009) Thermal tolerance of the coffee berry borer Hypothenemus hampei: predictions of climate change impact on a tropical insect pest. PloS one 4, e6487. 
Jaramillo, J., Muchugu, E., Vega, F.E., Davis, A., Borgemeister, C., Chabi-Olaye, A. (2011) Some like it hot: the influence and implications of climate change on coffee berry borer (Hypothenemus hampei) and coffee production in East Africa. PloS one 6, e24528.

Keeley, J., Scoones, I. (2000) Knowledge, power and politics: the environmental policy-making process in Ethiopia. The Journal of Modern African Studies 38, 89-120.

Keeley, J., Scoones, I. (2004) Understanding policy processes in Ethiopia: a response. The Journal of Modern African Studies 42, 149-153.

Kew, S., (2013) Building a climate resilient coffee economy for Ethiopia.

Kull, C.A., de Sartre, X.A., Castro-Larrañaga, M. (2015) The political ecology of ecosystem services. Geoforum 61, 122-134.

Kull, C.A., Rangan, H., (2016) Political ecology and resilience: competing interdisciplinarities?, in:

Hubert, N., Mathieu, N. (Eds.), Interdisciplinarités entre Natures et Sociétés. Peter Lang, Brussels.

Labouisse, J.-P., Bellachew, B., Kotecha, S., Bertrand, B. (2008) Current status of coffee (Coffea

arabica L.) genetic resources in Ethiopia: implications for conservation. Genetic Resources and Crop

Evolution 55, 1079-1093.

Lavers, T. (2012) 'Land grab' as development strategy? The political economy of agricultural investment in Ethiopia. The Journal of Peasant Studies 39, 105-132.

López-Bravo, D. F., Virginio-Filho, E. D. M., \& Avelino, J. (2012). Shade is conducive to coffee rust as compared to full sun exposure under standardized fruit load conditions. Crop Protection, 38, 21-29.

Lin, B. B. (2007). Agroforestry management as an adaptive strategy against potential microclimate extremes in coffee agriculture. Agricultural and Forest Meteorology, 144(1-2), 85-94.

Marino, E., Ribot, J. (2012) Special Issue Introduction: Adding insult to injury: Climate change and the inequities of climate intervention. Global Environmental Change 22, 323-328.

Martin, B. R. (2011) The Research Excellence Framework and the 'impact agenda': are we creating a Frankenstein monster?. Research Evaluation, 20(3), 247-254.

Mauro, S.E.-D. (2009) Seeing the local in the global: Political ecologies, world-systems, and the question of scale. Geoforum 40, 116-125.

Mehrabi, Z., Lashermes, P. (2017) Protecting the origins of coffee to safeguard its future. Nature Plants 3, 16209.

Meyer, F.G., Fernie, L., Narasimhaswamy, R., Monaco, L., Greathead, D. (1968) FAO Coffee Mission to Ethiopia, 1964-1965. FAO Rome, Italy.

Miles, M.B., Huberman, A.M. (1994) Qualitative data analysis: An expanded sourcebook. Sage. Moat, J., Williams, J., Baena, S., Wilkinson, T., Gole, T.W., Challa, Z.K., Demissew, S., Davis, A.P. (2017) Resilience potential of the Ethiopian coffee sector under climate change. 3, 17081. Moser, S. C., \& Ekstrom, J. A. (2010). A framework to diagnose barriers to climate change adaptation. Proceedings of the national academy of sciences, 107(51), 22026-22031.

Nyssen, J., Haile, M., Moeyersons, J., Poesen, J., Deckers, J. (2004) Environmental policy in Ethiopia: a rejoinder to Keeley and Scoones. The Journal of Modern African Studies 42, 137-147.

Olsson, P., Gunderson, L.H., Carpenter, S.R., Ryan, P., Lebel, L., Folke, C., Holling, C.S. (2006) Shooting the rapids: navigating transitions to adaptive governance of social-ecological systems. Ecology and Society $11,18$.

Ostrom, E. (2010) Beyond Markets and States: Polycentric Governance of Complex Economic Systems. Transnational Corporations Review 2, 1-12.

Ovalle-Rivera, O., Läderach, P., Bunn, C., Obersteiner, M., Schroth, G. (2015) Projected shifts in Coffea arabica suitability among major global producing regions due to climate change. PloS one 10 , e0124155.

Perfecto, I., Vandermeer, J. (2015) Coffee Agroecology: A new approach to understanding agricultural biodiversity, ecosystem services and sustainable development. Routledge. 
Perfecto, I., Vandermeer, J., Mas, A., Pinto, L.S. (2005) Biodiversity, yield, and shade coffee certification. Ecological Economics 54, 435-446.

Petit, N. (2007) Ethiopia's Coffee Sector: A Bitter or Better Future? Journal of Agrarian Change 7, 225-263.

Ponte, S. (2002a) Brewing a Bitter Cup? Deregulation, Quality and the Re-organization of Coffee Marketing in East Africa. Journal of Agrarian Change 2, 248-272.

Ponte, S. (2002b) The 'Latte Revolution'? Regulation, Markets and Consumption in the Global Coffee Chain. World Development 30, 1099-1122.

Punch, K.F. (2013) Introduction to social research: Quantitative and qualitative approaches. Sage. Putzel, L., Kelly, A.B., Cerutti, P.O., Artati, Y. (2015) Formalization as development in land and natural resource policy. Society \& Natural Resources $28,453-472$.

RA, (2010) Assessing resilience in social-ecological systems: Workbook for practitioners. Resilience Alliance.

Rahmato, D. (2014) The perils of development from above: land deals in Ethiopia. African Identities 12, 26-44.

Robbins, P. (2012) Political ecology: A critical introduction. John Wiley \& Sons.

Senbeta, F., Denich, M. (2006) Effects of wild coffee management on species diversity in the Afromontane rainforests of Ethiopia. Forest Ecology and Management 232, 68-74.

Soto-Pinto, L., Perfecto, I., Castillo-Hernandez, J., Caballero-Nieto, J. (2000) Shade effect on coffee production at the northern Tzeltal zone of the state of Chiapas, Mexico. Agriculture, Ecosystems \& Environment 80, 61-69.

Tadesse, F., (2015) Fertilizer Factory Construction Resumes after 10 Months. Addis Fortune.

Tefera, A., (2012) USDA - Ethiopia Coffee Annual Report, Global Agricultural Information Network. United States Department of Agriculture.

UNCOMTRAD, (2014) Coffee and coffee substitutes. UN Comtrade and UN ServiceTrade.

UNDP, (2015) National Human Development Report 2015 Ethiopia - Accelerating Inclusive Growth for Sustainable Human Development in Ethiopia, Human Development Reports. United National Developing Programme Addis Ababa, Ethiopia.

van der Vossen, H., Bertrand, B., Charrier, A. (2015) Next generation variety development for sustainable production of arabica coffee (Coffea arabica L.): a review. Euphytica 204, 243-256. Vanderhaegen, K., Verbist, B., Hundera, K., Muys, B. (2015) REALU vs. REDD+: Carbon and biodiversity in the Afromontane landscapes of SW Ethiopia. Forest Ecology and Management 343, 22-33.

Vlek, P. (2001) 23 Human Impacts on the Coffea arabica Genepool in Ethiopia and the Need for its in situ Conservation. Managing plant genetic diversity, 237.

Walker, B., Holling, C.S., Carpenter, S., Kinzig, A. (2004) Resilience, adaptability and transformability in social-ecological systems. Ecology and Society 9. 